\title{
SIGNAL MEDIATORS AT INDUCTION OF HEAT RESISTANCE OF WHEAT PLANTLETS BY SHORT-TERM HEATING
}

\author{
Yu. V. KARPETS, Yu. E. KOLUPAEV, T. O. YASTREB
}

\author{
V. V. Dokuchaev Kharkiv National Agrarian University, Ukraine; \\ e-mail:plant_biology@mail.ru
}

The effects of functional interplay of calcium ions, reactive oxygen species (ROS) and nitric oxide (NO) in the cells of wheat plantlets roots (Triticum aestivum L.) at the induction of their heat resistance by a shortterm influence of hyperthermia (heating at the temperature of $42{ }^{\circ} \mathrm{C}$ during 1 minute) have been investigated. The transitional increase of $\mathrm{NO}$ and $\mathrm{H}_{2} \mathrm{O}_{2}$ content, invoked by heating, was suppressed by the treatment of plantlets with the antagonists of calcium EGTA (chelator of exocellular calcium), lanthanum chloride (blocker of calcium channels of various types) and neomycin (inhibitor of phosphatidylinositol-dependent phospholipase C). The rise of hydrogen peroxide content, caused by hardening, was partially suppressed by the action of inhibitors of nitrate reductase (sodium wolframate) and NO-synthase ( $N^{G}$-nitro-L-arginine methyl ester - L-NAME), and the increasing of nitric oxide content was suppressed by the treatment of plants with the antioxidant ionol and with the scavenger of hydrogen peroxide (dimethylthiourea). These compounds and antagonists of calcium also partially removed the effect of the rise of plantlets' heat resistance, invoked by hardening heating. The conclusion on calcium's role in the activation of enzymatic systems, generating reactive oxygen species and nitric oxide, and on the functional interplay of these signal mediators at the induction of heat resistance of plantlets by hardening heating is made.

Key words: calcium, nitric oxide, reactive oxygen species, stress signalling, heat resistance, Triticum aestivum L.

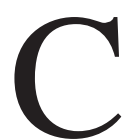

alcium ions, reactive oxygen species (ROS) and nitric oxide (NO) serve as the mediators that are in close functional interplay at the transduction of various stress signals to the genetic apparatus of plant cell [1-3]. The induction of protective reactions, leading to the development of plants resistance to stress influences, occurs to the participation of these signal mediators [4].

So, it is shown that the calcium ions, hydrogen peroxide and nitric oxide serve as the mediators in the stress-induced closing of stomas. The treatment of Arabidopsis leaves with $10 \mathrm{mM}$ calcium chloride invoked the increase of content of hydrogen peroxide and nitric oxide in cells and the closing of stomas. The given effects were suppressed both by the catalase, and the scavenger of nitric oxide PTIO (2-phenyl-4,4,5,5-tetramethylimidazoline-1-oxyl-3-oxide) [5]. There is a reason to suppose that the hydrogen peroxide plays the role of an inducer, causing the accumulation of NO, which is directly involved in the regulation of the state of stomas [6]. In Arabidopsis mutants AtrbohD/F, defective in the activity of NADPH oxidase and not producing enough hydrogen peroxide, the closing of stomas, induced by the action of UF-B, did not take place. However the treatment of these plants with the donor of NO led to the ability of implication to close stomas. On the other hand, the treatment with hydrogen peroxide of mutants nia1-2, defective in nitric oxide synthesis, did not cause similar effect [6].

It is established that the intensifying of NO synthesis in the cells of mung bean plants (Phaseolus aureus), stimulated by the influence of exogenous hydrogen peroxide, depended on the calcium influx to cytosol through the potential-dependent calcium channels [7]. Under the action of copper ions on the culture of sea alga Ulva compressa, the rise of the content of nitric oxide, hydrogen peroxide and calcium ions in cells was registered after 2 and 12 hours [8]. Thus the treatment of cells with the NO scavenger levelled the increase of the concentration of endocellular calcium, and the antagonists of calcium removed the rise of NO content. At the same time, the increase of hydrogen peroxide content in 
the cells at different stages of the experiment was taken out by the blockers of calcium channels, but was not taken out by the nitric oxide scavenger.

Earlier the participation of hydrogen peroxide [9] and nitric oxide [10] as the signal mediators at the induction of heat resistance of wheat plantlets by short-term hardening heating has been shown by us. However, the role of calcium homeostasis in the regulation of content of these mediators in connection with the heat resistance development was not investigated. At the same time, the possibility of induction of heat resistance of plant objects by exogenous calcium and the involvement of ROS [11] and nitric oxide [12] in this process are demonstrated. Besides, at the response of plants to the influence of hyperthermia, the fast enough increase of the content of cytosolic calcium in cells [13] is registered. As a whole, the literary data suggests difficult functional crosslinks between $\mathrm{Ca}^{2+}, \mathrm{H}_{2} \mathrm{O}_{2}$ and $\mathrm{NO}$ at the perception of stress signals by plants. However, their locating in signal chains at the induction of those or other physiological responses to external influences remains a little studied area.

Possible functional interplay between $\mathrm{Ca}^{2+}$ ions, NO and ROS in the cells of wheat plantlets roots at the induction of their heat resistance by short-term heating, applying the inhibitory method with the use of antagonists of calcium and nitric oxide, and antioxidants, has been investigated in the paper.

\section{Materials and Methods}

The etiolated plantlets of soft winter wheat (Triticum aestivum L.) of Elegiya variety, which has been grown up on the cleared tap water at a temperature of $22^{\circ} \mathrm{C}$, served as the experimental object. The roots of intact three-day plantlets of appropriate experiment treatments during 24 hours have been exposed to the solutions of chelator of "external" calcium (EGTA), blocker of calcium channels of different types (lanthanum chloride), inhibitor of phosphatidylinositol-specific phospholipase C (neomycin), antioxidants (ionol (butilgidroksitoluol) or dimethylthioureas (DMTU)), inhibitors of NOsynthase $\left(\mathrm{N}^{\mathrm{G}}\right.$-nitro-L-arginine methyl ester (LNAME)) and nitrate reductase (sodium wolframate). Control plantlets have been continued to be incubated on water at this time. The required concentrations of indicated compounds (EGTA - $500 \mu \mathrm{M}$, $\mathrm{LaCl}_{3}-5 \mathrm{mM}$, neomycin $-200 \mu \mathrm{M}$, ionol $-50 \mu \mathrm{M}$, DMTU - $150 \mu \mathrm{M}$, L-NAME - $2 \mathrm{mM}, \mathrm{Na}_{2} \mathrm{WO}_{4}-$ $1 \mathrm{mM}$ ), which substantially reduced the positive in- fluence of hardening heating on the heat resistance of plantlets, were chosen on the basis of preliminary experiments.

After the treatment with investigated compounds, the part of plantlets have been exposed to one-minute hardening heating in a water ultrathermostat at a temperature of $42.0 \pm 0.1^{\circ} \mathrm{C}[9,10]$. Then the plant material of appropriate treatments was carried again to the solutions of investigated compounds and kept in them $24 \mathrm{~h}$ till the moment of testing (potentially lethal) heating. The plants, which were not treated with the inhibitors, have been incubated on the water all the time. As it was established earlier, the maximum heat resistance of plantlets was developed $24 \mathrm{~h}$ after the hardening heating [9]. At this moment, to determine their heat resistance the plantlets were exposed to the potentially lethal heating in a water ultrathermostat at a temperature of $46.0 \pm 0.1{ }^{\circ} \mathrm{C}$ during $10 \mathrm{~min}$. The relative quantity of survived plantlets was estimated during 4 days after the influence of damaging heating.

The hydrogen peroxide content has been quantified using the ferrothiocyanide method with the extracting from homogenised roots by $5 \%$ trichloroacetic acid in the cold. Homogenate has been centrifuged at $8000 \mathrm{~g}$ during $10 \mathrm{~min}$ at a temperature no more than $4{ }^{\circ} \mathrm{C}$, and after that the concentration of $\mathrm{H}_{2} \mathrm{O}_{2}$ was quantified in supernatant with the use of Mohr's salt and ammonium thiocyanide [14]. As the standard, the hydrogen peroxide solutions was used.

The NO content in plantlets roots was analyzed with the use of Griess reagent by the method described by Zhou et al. [15] with the modifications as detailed previously [10].

Experiments were reproduced independently three times in triple replication within each individual experiment. The mean values and their standard errors are shown on figures. The significance of differences between treatments was assessed by Student $t$-test. The effects, significant at $P \leq 0.05$, are discussed.

Reagents: L-NAME and neomycin - Sigma (USA), DMTU - Merck (Germany), ionol - Fluka (USA), EGTA - AppliChem (Germany), other reagents - chemically pure or analytically pure grade of domestic production.

\section{Results and Discussion}

As it has been earlier established by us, after hardening heating the transitional increase of the content of hydrogen peroxide and nitric oxide was 
observed in the roots of wheat plantlets [10]. Thus, the maximum values of the amount of hydrogen peroxide and nitric oxide were registered accordingly $15 \mathrm{~min}$ and $1 \mathrm{~h}$ after the influence of hardening temperature. Thereby, in this study the content of $\mathrm{H}_{2} \mathrm{O}_{2}$ in roots was analyzed $15 \mathrm{~min}$, and $\mathrm{NO}-1 \mathrm{~h}$ after hardening heating.

The hardening heating invoked the increase of the content of hydrogen peroxide in roots (Fig. 1, A). The preliminary treatment of plantlets with EGTA caused small, but significant (at $P \leq 0.05$ ) decrease of hydrogen peroxide content in roots. EGTA substantially suppressed the effect of the increase of $\mathrm{H}_{2} \mathrm{O}_{2}$ content in roots, invoked by the hardening influence. Pretreatment of plantlets with lanthanum chloride in itself did not essentially influence the content of $\mathrm{H}_{2} \mathrm{O}_{2}$ in roots, however almost completely levelled the effect of hardening of plantlets on this parameter. Neomycin also did not have the appreciable influence on the hydrogen peroxide content in plantlets roots, but this compound suppressed the increase of $\mathrm{H}_{2} \mathrm{O}_{2}$ amount in roots, caused by hardening heating.

Under the influence of hardening heating, the increase of nitric oxide content in the roots of wheat plantlets took place (Fig. 1, B). The treatment of plantlets with EGTA, lanthanum chloride or neomycin did not render the significant effect on the amount of NO in roots. Thus all three antagonists of calcium removed the effect of the increase of NO content in roots, invoked by the hardening influence.
The treatment of plantlets with the antagonists of calcium did not influence their constitutive resistance to the damaging heating (Fig. 2). However, EGTA, $\mathrm{LaCl}_{3}$ and neomycin partially removed the development of induced heat resistance after the hardening heating of plantlets.

The literary data allows us to suppose not only the dependence of content of ROS and nitric oxide in cells on the calcium homeostasis [16, 17], but also the possibility of cross influence of NO on the content of $\mathrm{H}_{2} \mathrm{O}_{2}$ in tissues and conversely [18]. In our experiments the pretreatment of plantlets roots with the antioxidant ionol and the scavenger of hydrogen peroxide DMTU in itself reduced the hydrogen peroxide content in roots, and in the combination with hardening removed the invoked increase of $\mathrm{H}_{2} \mathrm{O}_{2}$ amount in tissues (Fig. 3, A). Thus, both antioxidants also prevented the increase of NO content in roots after the hardening heating of plantlets (Fig. 3, B).

On the other hand, the inhibitor of NO-synthase L-NAME, without rendering the essential influence on nitric oxide contents in plantlets roots in usual conditions, prevented its increase caused by hardening heating (Fig. 3, B). Thus, this inhibitor partially removed the increase of the content of hydrogen peroxide in roots, invoked by the influence of hyperthermia (Fig. 3, A). The similar effect was also caused by the treatment of plantlets with sodium wolframate - the inhibitor of nitrate reductase (another enzyme, probably, participating in the NO
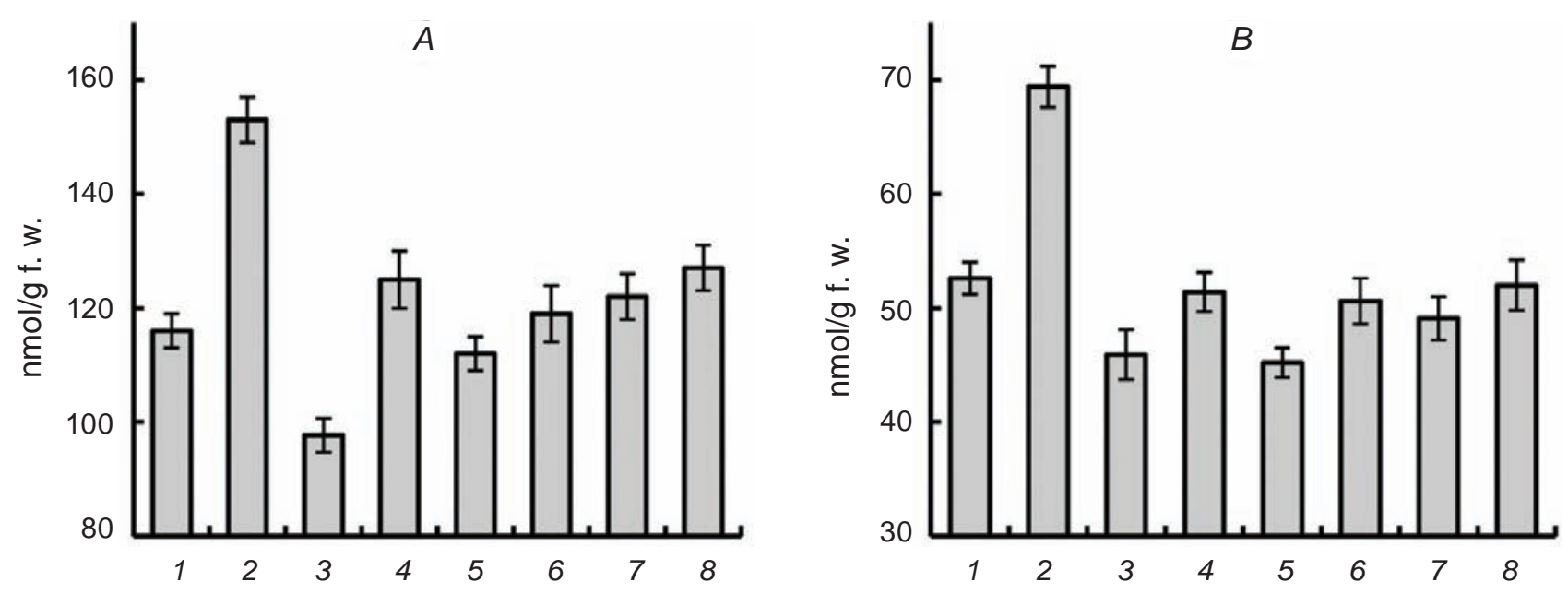

Fig. 1. Influence of antagonists of calcium on content of hydrogen peroxide (A) and nitric oxide (B) in wheat plantlets roots after hardening heating. Here and in Fig. 2: 1 - control; 2 - hardening heating $\left(42{ }^{\circ} \mathrm{C}, 1 \mathrm{~min}\right)$; 3 - EGTA $(500 \mu \mathrm{M}) ; 4$ - hardening heating + EGTA; 5 - $\mathrm{LaCl}_{3}(5 \mathrm{mM}) ; 6$ - hardening heating $+\mathrm{LaCl}_{3}$; 7 neomycin $(200 \mu M) ; 8$ - hardening heating + neomycin 


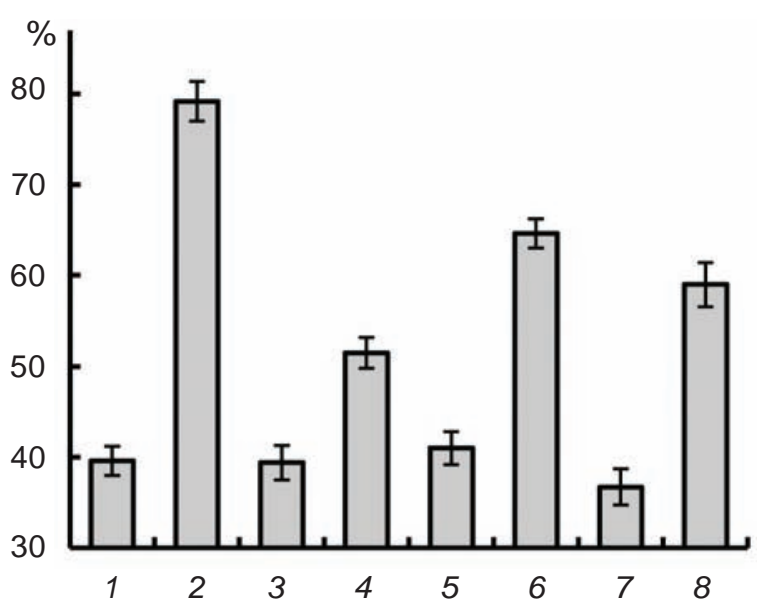

Fig. 2. Influence of antagonists of calcium on survival of wheat plantlets after damaging heating $\left(46{ }^{\circ} \mathrm{C}, 10 \mathrm{~min}\right)$

synthesis). Under its influence, the effects of the increase of the content of both $\mathrm{NO}$ and $\mathrm{H}_{2} \mathrm{O}_{2}$, invoked by hardening heating in roots tissues, were partially levelled (Fig. 3).

Antioxidants and antagonists of NO partially removed the effect of rising of the heat resistance of plantlets, induced by hardening heating (Fig. 4). It is necessary to note that thus in itself the antioxidants invoked the tendency to slightly increase the plantlets resistance to damaging heating that can be bound to their direct protective antioxidative

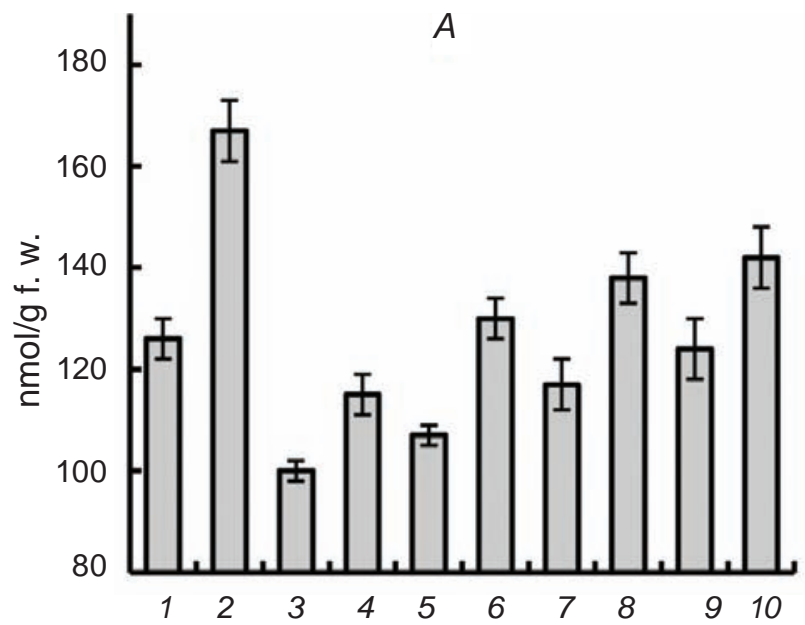

influence, which, however, was much weaker than the hardening effect. Remarkable that the inhibitor of NO-synthase L-NAME caused also small, but significant (at $P \leq 0.05$ ) increase of the heat resistance of wheat plantlets (Fig. 4). It is difficult to explain this effect without special investigations. Probably, the NO decrease in cells in itself serves as a stressfactor activating the plant protective systems [19]. Earlier the increase of activity of antioxidative enzymes superoxide dismutase, catalase and guaiacol peroxidase has been shown by us under the influence of NO scavenger PTIO and NO-synthase inhibitor L-NAME on wheat plantlets [20].

As a whole, the received results suggest the participation of all three investigated signal mediators - calcium, hydrogen peroxide and nitric oxide in the processes causing the development of heat resistance of wheat plantlets, invoked by hardening heating. So, the antagonists of calcium of various nature, as well as antioxidants and inhibitors of enzymes involved in NO synthesis prevented the implication of effects of hardening (Fig. 2, 4). Thus the antagonists of calcium prevented the increase of content both hydrogen peroxide and nitric oxide in roots after hardening heating.

It may be supposed that the hardening heating of plantlets invokes the calcium-dependent increase of activity of enzymes generating ROS and nitric oxide. Earlier on the model used in the present study it has been shown that the rise of content of hydro-

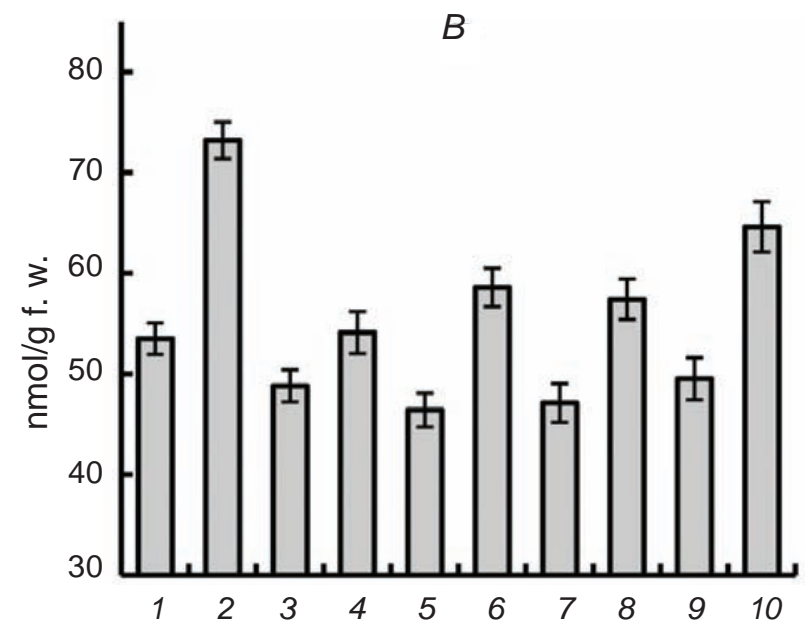

Fig. 3. Influence of antioxidants and inhibitors of NO-synthase and nitrate reductase on content of hydrogen peroxide (A) and nitric oxide (B) in wheat plantlets roots after hardening heating. Here and in Fig. 4: 1 control; 2 - hardening heating $\left(42^{\circ} \mathrm{C}, 1 \mathrm{~min}\right) ; 3$ - ionol $(50 \mu \mathrm{M}) ; 4$ - hardening heating + ionol; 5 -DMTU (150 $\mu M) ; 6$ - hardening heating + DMTU; 7 - L-NAME (2 mM); 8 - hardening heating + L-NAME; 9 $\mathrm{Na}_{2} \mathrm{WO}_{4}(1 \mathrm{mM}) ; 10$ - hardening heating $+\mathrm{Na}_{2} \mathrm{WO}_{4}$ 


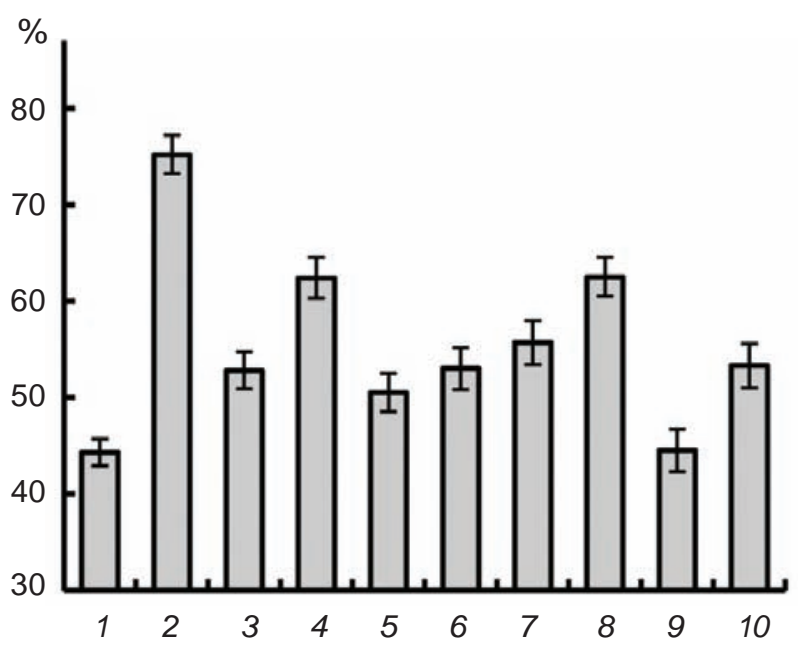

Fig. 4. Influence of antioxidants and inhibitors of NO-synthase and nitrate reductase on survival of wheat plantlets after damaging heating $\left(46{ }^{\circ} \mathrm{C}\right.$, $10 \mathrm{~min}$ )

gen peroxide in roots, that takes place $10-30 \mathrm{~min}$ after hardening heating, is bound to the increase of the activity of NADPH oxidase and superoxide dismutase [9]. It is known that the NADPH oxidase, serving as the main enzyme, generating the "signal” ROS [21], is activated with the involvement of calcium [2]. This is consistent with the received data about the inhibition of $\mathrm{H}_{2} \mathrm{O}_{2}$ content increase in roots, invoked by heating, by the various calcium antagonists. Apparently, in the activation of enzymatic systems generating ROS, the «external» calcium is involved, since the increase of the content of hydrogen peroxide in roots, caused by heating, was suppressed not only by the blocker of calcium channels of various types (lanthanum chloride), but also by the chelator of "external" calcium EGTA. On the other hand, the effect of the increase of $\mathrm{H}_{2} \mathrm{O}_{2}$ content was also levelled by neomycin influence. This compound, binding phosphatidylinositol biphosphates, can inhibit the phosphatidylinositol-specific phospholipase C [22] and thus prevent the accumulation of reaction product inozitol-1,4,5-phosphate $\left(\mathrm{IP}_{3}\right)$, which influences calcium influx in the cytosol from endocellular compartments [23].

In spite of the fact that the homologues of the $\mathrm{IP}_{3}$ targets have not been detected in plants till now, it is proved that neomycin can reduce the calcium influx in the cytosol of plant cells from the endocellular compartments [24]. At the same time there are not enough grounds to associate unequivocally the suppression of increase of hydrogen peroxide content in roots, induced by hyperthermia, with the influence of neomycin on the calcium homeostasis, since it can also exert an indirect influence on the NADPH oxidase activity, bound to the change of content of phosphatidic acid [25], which, along with calcium, can bind to NADPH-oxidase and by that to participate in the intensifying of ROS generation [17]. Nevertheless, experiments with the use of various antagonists of calcium allow to suppose that the increase of hydrogen peroxide content in roots, induced by hardening heating, is a calcium-dependent process.

Enzymatic systems, that generate NO, and are, probably, activated under the influence of hardening heating, also serve as calcium-dependent ones. In plant cells the enzyme, similar to the NO-synthase of animals [16], and the nitrate reductase [26] are considered as the main enzymatic sources of nitric oxide. There are grounds to suppose that both these enzymes are involved to some extent in the increase of content of nitric oxide induced by heating in the roots of plantlets. This effect was suppressed by both the inhibitor of NO-synthase L-NAME, and the inhibitor of nitrate reductase sodium wolframate (Fig. 3, B).

It is known that the plant enzyme, similar to the NO-synthase of animals, is activated with the calcium and/or calmodulin involvement [16, 27]. It agrees well with the phenomenon revealed by us, which is the effect of suppression of the increase of NO content in roots, invoked by the hyperthermia, by the calcium antagonists (Fig. 1, B). At the same time, the dependence of activity of other source of $\mathrm{NO}$ - nitrate reductase - on the calcium ions is not proved yet [27]. On the other hand, it is allowed the possibility of calcium influence on the activity of nitrate reductase through the cascade of reactions, in which ROS and protein kinases are involved [28, 29]. Thus, as a whole, there is a reason to state the dependence of the content of NO and ROS in plant cells on the calcium homeostasis.

At the same time, the functional interplay takes place also between hydrogen peroxide and nitric oxide. The suppression of the accumulation of hydrogen peroxide, stimulated with hardening heating in the roots of plantlets, by the influence of inhibitors of both NO-synthase and nitrate reductase gives evidence to it (Fig. 3, A). On the other hand, the antioxidants ionol and DMTU suppressed the increase of NO content invoked by heating in wheat roots (Fig. 3, B). There are data in the literature, that the 
nitric oxide can influence the enzymatic systems generating ROS, in particular, NADPH oxidase [30], and also antioxidative enzymes [19] and thus regulate the content of ROS. The influence of ROS on the activity of NO-generating enzymes is less investigated. However, besides the facts of the rising of NO content in the plant tissues under the influence of exogenous hydrogen peroxide [10,31], there is also data about the activation of nitrate reductase under the influence of hydrogen peroxide [32].

In turn, the effects of ROS and nitric oxide as signal mediators are realized with the calcium involvement. Both ROS and NO are capable of changing the state of calcium channels of different types, and therefore may exert the influence on many calcium-dependent processes [33-35]. The discussion of these issues is beyond the experimental material of this article. It should be only noted that calcium, apparently, is located in the different parts of signal chains participating in the formation of adaptive responses of plants [3]. As a whole, there are the grounds to confirm the close functional interplay between calcium, ROS and NO at the induction of heat resistance of wheat plantlets by short-term heating. The antagonists of calcium blocked the increase of both ROS and NO content in the plant tissues. On the other hand, the antagonists of NO prevented the raise of the content of hydrogen peroxide in roots, and antioxidants suppressed the increase of NO content in them. Thus the antagonists of calcium, antioxidants and inhibitors of enzymes, generating nitric oxide, considerably prevented the development of heat resistance of plantlets after hardening heating.

Publications are based on the research provided by the grant support of the State Fund For Fundamental Research (project N F61/74-2015).

\section{СИГНАЛЬНІ ПОСЕРЕДНИКИ ЗА ІНДУКУВАННЯ ТЕПЛОСТІЙКОСТІ ПРОРОСТКІВ ПШЕНИЦІ КОРОТКОЧАСНИМ ПРОГРІВОМ}

\section{Ю. В. Карпеи̧ь, Ю. Є. Колупаєв, T. О. Ястреб}

\author{
Харківський національний аграрний \\ університет ім. В. В. Докучаєва, Україна; \\ e-mail: plant_biology@mail.ru
}

Досліджували ефекти функціональної взаємодії іонів кальцію, активних форм кисню (АФК) та оксиду азоту (NO) в клітинах коренів проростків пшениці (Triticum aestivum L.) за індукування розвитку їх теплостійкості короткочасною дією гіпертермії (прогрів за температури $42{ }^{\circ} \mathrm{C}$ протягом 1 хв). Транзиторне збільшення вмісту $\mathrm{NO}$ i $\mathrm{H}_{2} \mathrm{O}_{2}$, спричинене прогрівом, пригнічувалося обробкою проростків антагоністами кальцію ЕГТА (хелатор позаклітинного кальцію), хлоридом лантану (блокатор кальцієвих каналів різних типів) і неоміцином (інгібітор фосфатидилінозитолзалежної фосфоліпази C). Спричинене загартовуванням збільшення вмісту пероксиду водню частково знімалося дією інгібіторів нітратредуктази (вольфрамату натрію) i NO-синтази ( $\mathrm{N}^{\mathrm{G}}$-nitro-L-arginine methyl ester - L-NAME), а підвищення вмісту оксиду азоту пригнічувалося обробкою рослин антиоксидантом іонолом і скавенджером пероксиду водню диметилтіосечовиною. Ці сполуки i антагоністи кальцію також частково знімали ефект підвищення теплостійкості проростків, спричинений загартовуючим прогрівом. Зроблено висновок про роль кальцію в активації ензиматичних систем, що генерують активні форми кисню і оксид азоту, та у функціональній взаємодії цих сигнальних посередників за індукування теплостійкості проростків загартовуючим прогрівом.

К л ючов і слов а: кальцій, оксид азоту, активні форми кисню, стресовий сигналінг, теплостійкість, Triticum aestivum L.

\section{СИГНАЛЬНЫЕ ПОСРЕДНИКИ ПРИ ИНДУЦИРОВАНИИ \\ ТЕПЛОУСТОЙЧИВОСТИ ПРОРОСТКОВ ПШЕНИЦЫ КРАТКОВРЕМЕННЫМ ПРОГРЕВОМ}

\section{Ю. В. Карпец, Ю. Е. Колупаев, Т. О. Ястреб}

$$
\begin{gathered}
\text { Харьковский национальный аграрный } \\
\text { университет им. В. В. Докучаева, Украина; } \\
\text { e-mail: plant_biology@mail.ru }
\end{gathered}
$$

Исследовали эффекты функционального взаимодействия ионов кальция, активных форм кислорода (АФК) и оксида азота (NO) в клетках корней проростков пшеницы (Triticum aestivum L.) при индуцировании развития их теплоустойчивости кратковременным действием гипертермии (прогрев при температуре $42^{\circ} \mathrm{C}$ в течение 1 мин). Транзиторное увеличение со- 
держания $\mathrm{NO}$ и $\mathrm{H}_{2} \mathrm{O}_{2}$, вызываемое прогревом, угнеталось обработкой проростков антагонистами кальция ЭГТА (хелатор внеклеточного кальция), хлоридом лантана (блокатор кальциевых каналов различных типов) и неомицином (ингибитор фосфатидилинозитолзависимой фосфолипазы С). Вызываемое закаливанием увеличение содержания пероксида водорода частично подавлялось действием ингибиторов нитратредуктазы (вольфрамата натрия) и NO-синтазы ( $\mathrm{N}^{\mathrm{G}}$-nitro-L-arginine methyl ester - L-NAME), a повышение содержания оксида азота угнеталось обработкой растений антиоксидантом ионолом и скавенджером пероксида водорода диметилтиомочевиной. Эти соединения и антагонисты кальция также частично снимали эффект повышения теплоустойчивости проростков, вызываемый закаливающим прогревом. Сделано заключение о роли кальция в активации энзиматических систем, генерирующих активные формы кислорода и оксид азота, и в функциональном взаимодействии этих сигнальных посредников при индуцировании теплоустойчивости проростков закаливающим прогревом.

К л ю че в ы е с л о в а: кальций, оксид азота, активные формы кислорода, стрессовый сигналинг, теплоустойчивость, Triticum aestivum L.

\section{References}

1. Kaur N., Gupta A. K. Signal transduction pathways under abiotic stresses in plants. Curr. Sci. 2005; 88: 1771-1780.

2. Baxter A., Mittler R., Suzuki N. ROS as key players in plant stress signalling. J. Exp. Bot. 2014; 65(5): 1229-1240.

3. Jeandroz S., Lamotte O., Astier J., Rasul S., Trapet P., Besson-Bard A., Bourque S., NicolasFrances V., Berkowitz G. A., Wendehenne D. There's more to the picture than meets the eye: nitric oxide cross talk with $\mathrm{Ca}^{2+}$ signaling. Plant Physiol. 2013; 163(2): 459-470.

4. Tuteja N., Sopory S. K. Chemical signaling under abiotic stress environment in plants. Plant Signal. Behav. 2008; 3(8): 525-536.
5. Wang W. H., Yi X. Q., Han A. D., Liu T. W., Chen J., Wu F. H., Dong X. J., He J. X., Pei Z. M., Zheng H. L. Calcium-sensing receptor regulates stomatal closure through hydrogen peroxide and nitric oxide in response to extracellular calcium in Arabidopsis. J. Exp. Bot. 2012; 63(1): 177-190.

6. He J. M., Ma X. G., Zhang Y., Sun T. F., Xu F. F., Chen Y. P., Liu X., Yue M. Role and interrelationship of $\mathrm{G} \alpha$ protein, hydrogen peroxide, and nitric oxide in ultraviolet B-induced stomatal closure in Arabidopsis leaves. Plant Physiol. 2013; 161(3): 1570-1583.

7. Lum H. K., Butt Y. K. C., Lo S. C. L. Hydrogen Peroxide Induces a Rapid Production of Nitric Oxide in Mung Bean (Phaseolus aureus). Nitric Oxide: Biol. Chem. 2002; 6(2): 205-213.

8. Gonzalez A., Cabrera A. M., Henriquez M. J., Contreras R. A., Morales B., Moenne A. Cross talk among calcium, hydrogen peroxide, and nitric oxide and activation of gene expression involving calmodulins and calcium-dependent protein kinases in Ulva compressa exposed to copper excess. Plant Physiol. 2012; 158(3): 14511462.

9. Kolupaev Yu. E., Oboznyi A. I., Shvidenko N. V. Role of hydrogen peroxide in generation of a signal inducing heat tolerance of wheat seedlings. Russ. J. Plant Physiol. 2013; 60(2): 227-234.

10. Karpets Yu. V., Kolupaev Yu. E., Vayner A. A. Functional interaction between nitric oxide and hydrogen peroxide during formation of wheat seedling induced heat resistance. Russ. J. Plant Physiol. 2015; 62(1): 65-70.

11. Kolupaev Yu. Ye., Karpets Yu. V., Kosakivska I. V. The importance of reactive oxygen species in the induction of plant resistance to heat stress. Gen. Appl. Plant Physiol. 2008; 34(3/4): 251-266.

12. Karpets Yu. V., Kolupaev Yu. E. Influence of changes of calcium homeostasis on nitric oxide content in roots of wheat plantlets and their heat resistance. Fiziol. Rasten. Genet. 2015; 47: 175182. (In Russian).

13. Liu H. T., Li B., Shang Z. L., Li X. Z., Mu R. L., Sun D. Y., Zhou R. G. Calmodulin is involved in 
heat shock signal transduction in wheat. Plant Physiol. 2003; 132(3): 1186-1195.

14. Sagisaka S. The occurrence of peroxide in a perennial plant, Populus gelrica. Plant Physiol. 1976; 57(2): 308-309.

15. Zhou B., Guo Z., Xing J., Huang B. Nitric oxide is involved in abscisic acid-induced antioxidant activities in Stylosanthes guianensis. J. Exp. Bot. 2005; 56(422): 3223-3228.

16. Neill S., Bright J., Desikan R. Hancock J., Harrison J., Wilson I. Nitric oxide evolution and perception. J. Exp. Bot. 2008; 59(1): 25-35.

17. Marino D., Dunand C., Puppo A., Pauly N. A burst of plant NADPH oxidases. Trends Plant Sci. 2012; 17(1): 9-15.

18. Wilson I. D., Neill S. J., Hancock J. T. Nitric oxide synthesis and signalling in plants. Plant Cell Environ. 2008; 31(5): 622-631.

19. Vital S. A., Fowler R. W., Virgen A., Gossett D. R., Banks S. W., Rodriguez J. Opposing roles for superoxide and nitric oxide in the $\mathrm{NaCl}$ stressinduced upregulation of antioxidant enzyme activity in cotton callus tissue. Environ. Exp. Bot. 2008; 62(1): 60-68.

20. Karpets Yu. V., Kolupaev Yu. E., Yastreb T. O., Oboznyi A. I. Effects of NO status modification, heat hardening, and hydrogen peroxide on the activity of antioxidant enzymes in wheat seedlings. Russ. J. Plant Physiol. 2015; 62(3): 292-298.

21. Mittler R., Vanderauwera S., Suzuki N., Miller G., Tognetti V. B., Vandepoele K., Gollery M., Shulaev V., Van Breusegem F. ROS signaling: the new wave? Trends Plant Sci. 2011; 16(6): 300-309.

22. Liu H. T., Huang W. D., Pan Q. H., Weng F. H., Zhan J. C., Liu Y., Wan S. B., Liu Y. Y. Contributions of PIP2-specific-phospholipase C and free salicylic acid to heat acclimation induced thermotolerance in pea leaves. J. Plant Physiol. 2006; 163(4): 405-416.

23. Lee Y., Lee Y. Roles of phosphoinositides in regulation of stomatal movements. Plant Signal. Behav. 2008; 3(4): 211-213.

24. Lecourieux D., Mazars C., Pauly N., Ranjeva R., Pugin A. Analysis and effects of cytosolic free calcium increases in response to elicitors in
Nicotiana plumbaginifolia cells. Plant Cell. 2002; 14(10): 2627-2641.

25. Arisz S. A., van Wijk R., Roels W., Zhu J. K., Haring M. A., Munnik T. Rapid phosphatidic acid accumulation in response to low temperature stress in Arabidopsis is generated through diacylglycerol kinase. Front. Plant Sci. 2013; 4. doi: 10.3389/fpls.2013.00001.

26. Mur L. A. J., Mandon J., Persijn S., Cristescu S. M., Moshkov I. E., Novikova G. V., Hall M. A., Harren F. J. M., Hebelstrup K. H., Gupta K. J. Nitric oxide in plants: an assessment of the current state of knowledge. AoB Plants. 2013; pls052; doi:10.1093/aobpla/pls052.

27. Courtois C., Besson A., Dehan J., Bourque S., Dobrowolska G., Pugin A., Wendehenne D. Nitric oxide signalling in plants: interplays with $\mathrm{Ca}^{2+}$ and protein kinases. J. Exp. Bot. 2008; 59(2): 155-163.

28. Wang H. H., Huang J. J., Bi Y. R. Nitrate reductase-dependent nitric oxide production is involved in aluminum tolerance in red kidney bean roots. Plant Sci. 2010; 179(3): 281-288.

29. Glyan'ko A. K., Ishchenko A. A., Stepanov A. V. Influence of calcium and rhizobial infections (Rhizobium leguminosarum) on the dynamics of nitric oxide (NO) content in roots of etiolated pea (Pisum sativum L.) seedlings. Appl. Biochem. Microbiol. 2014; 50(6): 652-657.

30. Tewari R. K., Hahn E. J., Paek K. Y. Function of nitric oxide and superoxide anion in the adventitious root development and antioxidant defence in Panax ginseng. Plant Cell Rep. 2008; 27(3): 563-573.

31. Zhang A., Jiang M., Zhang J., Ding H., Xu S., Hu X., Tan M. Nitric oxide induced by hydrogen peroxide mediates abscisic acid-induced activation of the mitogen-activated protein kinase cascade involved in antioxidant defense in maize leave. New Phytol. 2007; 175(1): 36-50.

32. Dubovskaya L. V., Bakakina Y. S., Kolesneva E. V., Sodel D. L., McAinsh M. R., Hetherington A. M., Volotovski I. D. cGMPdependent ABA-induced stomatal closure in the ABA-insensitive Arabidopsis mutant abi1-1. New Phytol. 2011; 191(1): 57-69. 
33. Klausner R. D., Rouault T. A., Harford J. B. Regulating the fate of mRNA: the control of cellular iron metabolism. Cell. 1993; 72(1): 19-28.

34. Mori I. C., Schroeder J. S. Reactive oxygen species activation of plant $\mathrm{Ca}^{2+}$ channels. A signaling mechanism in polar growth, hormone transduction, stress signaling, and hypothetically mechanotransduction. Plant Physiol. 2004; 135(2): 702-708.
35. Richards S. L., Laohavisit A., Mortimer J. C., Shabala L., Swarbreck S. M., Shabala S., Davies J. M. Annexin 1 regulates the $\mathrm{H}_{2} \mathrm{O}_{2}$ induced calcium signature in Arabidopsis thaliana roots. Plant J. 2014; 77(1): 136-145.

Received 15.09.2015 